\title{
Customer Roles in Self-Service Technology Encounters in a Tourism Context
}

\author{
Petranka Kelly \\ Technological University Dublin, petranka15@gmail.com \\ Jennifer Lawlor \\ Technological University Dublin, jennifer.lawlor@tudublin.ie \\ Michael Mulvey \\ Technological University Dublin
}

Follow this and additional works at: https://arrow.tudublin.ie/tfschhmtart

Part of the E-Commerce Commons, Technology and Innovation Commons, and the Tourism and Travel Commons

\section{Recommended Citation}

Lawlor, J., Kelly, P. and Mulvey, M. (2016) Customer Roles in Self-Service Technology Encounters in a Tourism Context. Journal of Travel \& Tourism Marketing, April 2016.(Online). doi:10.1080/ 10548408.2016.1156612

This Article is brought to you for free and open access by the School of Tourism \& Hospitality Management at ARROW@TU Dublin. It has been accepted for inclusion in Articles by an authorized administrator of ARROW@TU Dublin. For more information, please contact arrow.admin@tudublin.ie, aisling.coyne@tudublin.ie, gerard.connolly@tudublin.ie.

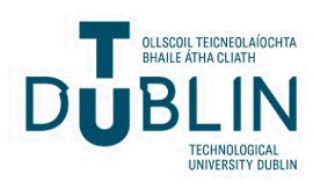




\title{
Customer Roles in Self-Service Technology Encounters in a Tourism Context
}

Petranka Kelly, Jennifer Lawlor*, Michael Mulvey

Dublin Institute of Technology, College of Arts and Tourism, Cathal Brugha Street, Dublin 1, Ireland.

*Corresponding author

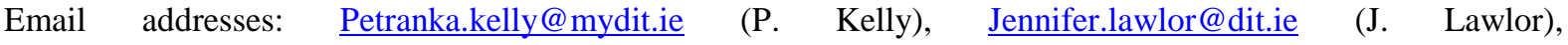
Michael.mulvey@dit.ie (M. Mulvey)

\begin{abstract}
This paper reports on a study which explored the customer perspective on their roles in SST encounters in a tourism context, through the theoretical lens of service-dominant logic. The study employed short qualitative interviews with airline passengers at an international airport. The findings suggest that customers can assume six roles in an SST encounter which can be viewed as either positive or negative in terms of value creation. Therefore, a key contribution of this paper is the development of a role-experience continuum which depicts the variations in customer experiences of value creation in a tourism context.
\end{abstract}

Keywords: self-service technologies, customer roles, service-dominant logic, co-creation

\section{INTRODUCTION}

Self-service technologies (SSTs) now constitute a norm in the contemporary marketplace (Collier, Moore, Horky, \& Moore, 2015; Elliott, Hall, \& Meng, 2013). SSTs range from wellestablished, traditional offerings, for example, online travel booking, to newer platforms, for example, mobile flight check-in facilities. The literature offers a broad consensus as to the benefits that accrue to the service organization implementing SSTs. These benefits include a reduction in operational costs and an increase in productivity, access to more customer segments and increased customer satisfaction and loyalty (Bitner, Ostrom, \& Meuter, 2002; Collier and Kimes, 2013; Lee, Castellanos, \& Choi, 2012). In addition, the literature has offered substantial insights into the conditions that underpin customers' use of SSTs. For 
example, the factors which affect a customer's usage of SSTs, range from user characteristics and attitudes (Gelderman, Ghijsen, \& Diemen, 2011; Lin \& Chang, 2011; Meuter, Bitner, Ostrom, \& Brown, 2005), demographics (Dean, 2008; Lee, Cho, Xu, \& Fairhurst, 2010), and technology characteristics (Meuter et al., 2005) to situational influences (Dabholkar \& Bagozzi, 2002; Simon \& Usunier, 2007; Wang, Harris, \& Patterson, 2012). More specifically, Kelly, Lawlor, \& Mulvey (2011) have identified seven of the most researched SST adoption factors in the literature, namely demographic variables (e.g. age, gender, income and education), trust, perceived risk, perceived ease of use, perceived usefulness, technology readiness and preference for personal contact.

Despite the extensive body of literature on factors affecting customer decisions to adopt SSTs, the actual customer production and consumption in SSTs, namely the co-creation of value, has received limited research attention (Baron, Patterson, \& Harris, 2006; Hilton, Hughes, Little, \& Marandi, 2013). Recent research has highlighted the phenomenological and context-bound nature of value co-creation and has called for research of value co-creation in specific service and cultural contexts (Akaka, Vargo \& Schau, 2015; McColl-Kennedy, Vargo, Dagger, Sweeney, \& Kasteren, 2012).

Within the service sector, the tourism industry has enthusiastically embraced SSTs and recognised the active role of customers in the delivery of the core service offering (Rosenbaum \& Wong, 2015). Yet, whilst customers' co-creation has been explored in a general service context (see for example Moeller, Ciuchita, Mahr, Odekerken-Schroeder, \& Fassnacht, 2013) and in a specific health context (McColl-Kennedy et al., 2012), there is a gap in the literature with regard to customer value co-creation when exposed to SSTs in a tourism context. In order to understand the customer perspective value co-creation in SSTs in tourism, this study draws on the Service-Dominant (S-D) Logic framework (Vargo \& Lusch, 
2004) and also examines the extant literature on customer service roles (see for example Bitner, Faranda, Hubbert, \& Zeithaml, 1997; Chervonnaya, 2003).

A deeper understanding of customer meanings and perceptions in a tourism context is important because it determines the creation of value in consumption experiences (Helkkula, Kelleher, \& Pihlstrom, 2012). For example, Lee et al., (2012) highlight the importance for airlines who have invested heavily in SSTs such as airline kiosks, to understand whether customers perceive these kiosks as helpful facilities or as obstacles in the service encounter. Similarly, there has been relatively little attention paid to customer experiences and reflections on co-creation in forced usage situations where they are required to use SSTs (Reinders, Dabholkar, \& Frambach, 2008), or voluntary usage situations, where they are given the choice of using SSTs or alternatively, interacting directly with a service employee (Lawlor, 2010; Ritzer \& Jurgenson, 2010).

A number of calls have been made by researchers to further understand value co-creation in tourism (see for example Grissemann \& Stokburger-Sauer, 2012; Polo Pena, Frias Jamilena, \& Rodriguez Molina, 2014; Shaw, Bailey, \& Williams, 2011). Therefore, this paper reports on a study involving 133 airline passengers in an international airport in Ireland. The objective of the study was to examine tourist interactions with SSTs by exploring the roles that customers are required to play (i.e. forced usage) or invited to play (i.e. voluntary usage) in these SST encounters, in the context of value co-creation.

This paper commences by reviewing the literature on customer roles in service delivery through the theoretical lens of the S-D Logic framework (Vargo \& Lusch, 2004). It then examines the qualitative research methodology employed in this study, and provides a discussion of the research findings. Finally, the paper explores the significance of these 
findings, considers their managerial implications, and offers recommendations for further research.

\section{S-D LOGIC AND CUSTOMER ROLES IN SERVICE}

The role of the customer as an active participant in service delivery is a well-established paradigm in the services management literature, even before the emergence of SSTs in services (Bitner et al., 1997; Chervonnaya, 2003; Lovelock \& Young, 1979; Mills \& Morris, 1986). Lovelock \& Young (1979) realized that one of the ways to increase company productivity and reduce costs was to involve customers in the service production process. Similarly, the central role of the customer as an operant resource in service value co-creation is a main proposition of the S-D Logic in marketing (Vargo \& Lusch, 2004), which renders it a suitable theoretical perspective to understand customer usage of SSTs (Hilton et al., 2013). The S-D Logic represents a marketing perspective which views market exchange and economic value creation as a process of relational exchange of operant resources between market players (Lusch, Vargo, \& Tanniru, 2010). The S-D Logic is represented in 10 Fundamental Premises (FPs) conceptualising the role of customers, firms and exchange in economic value creation (Vargo \& Lusch, 2008). The first five premises define market exchange as being service dominated (FP1), where the fundamental basis of exchange is indirect (FP2) and goods represent only a mechanism for service provision (FP3), but operant resources are the real source of competitive advantage (FP4) and a source of economic growth (FP5).

The remaining five FPs define service value in terms of how it is created and determined (Vargo \& Lusch, 2008). Value is created through customer interactions in the consumption process (FP6) where the provider only makes value propositions (FP7). The S-D Logic is service-oriented and relational (FP8) because value is created in a process of exchanges with 
the customer where all economic stakeholders integrate resources to co-create value (FP9) which is ultimately determined by the beneficiary (FP10).

Positive customer experiences with SSTs are dependent on active and effective customer participation in the delivery of the service (Meuter et al., 2005), which is reflected in FP6: 'the customer is always a co-creator of value' and FP10: 'value is always uniquely and phenomenologically determined by the beneficiary' (Vargo \& Lusch, 2008, p.7). The S-D Logic broadly defines the role of the customer in service as a co-creator of value which is a rather vague concept and has attracted much discussion and refinement (Grönroos \& Gummerus, 2014). A review of the relevant literature suggests that the customer as a cocreator may involve three roles, comprising a co-creator role in innovation (Roberts, Hughes, \& Kertbo, 2013), a co-creator role in the delivery and customization of the service (Moeller et al., 2013), and a co-creator role whereby customer resources are applied to derive value in consuming a service (Grönroos \& Gummerus, 2014). The co-creator of value concept in the S-D Logic incorporates all aspects of customer involvement in the production (co-producer) and consumption of the service which creates value for the customer (Grönroos, 2006). However, the co-creator customer role has been deemed to be too vague, requiring further development and operationalization for specific service contexts (Grönroos \& Gummerus, 2014; McColl-Kennedy et al., 2012). Therefore, this paper examines the literature on customer roles in service literature in order to refine the "co-creator of value" concept.

Service roles may represent the customer contributions to service, namely the customer as a productive resource, the customer as a contributor to satisfaction and value, and the customer as a competitor to the service organization (Bitner et al., 1997). Customer roles have also been represented as distinctive patterns of "visible" and "invisible" actions which customers perform in service situations (Chervonnaya, 2003). 
The S-D Logic perspective presupposes the involvement of customers in service development and innovation through co-creation (see for example, Edvardsson, Ng, Zhi Min, Firth, \& Yi, 2011; Graf, 2007; Matthing, Sandén, \& Edvardsson, 2004; Roberts et al., 2013; Shaw et al., 2011). The customer may undertake roles such as innovator (Graf, 2007), consultant (Ford \& Heaton, 2001) and instructor to the company (Chervonnaya, 2003). In a tourism context, Shaw et al. (2011) provide an understanding of the various ways in which tourism providers involve customers in innovation and highlight the importance of the company ability to facilitate co-creation as a major factor.

Co-creation also takes place when the customer becomes involved in the customization and co-production of the service in roles such as productive resource and contributor to quality, satisfaction and value (Bitner et al., 1997), partial employee (Mills \& Morris, 1986), ingredient (Chervonnaya, 2003), self-reliant customizer, bargain-hunting independent (Moeller et al., 2013), decision-maker and hunter (Chervonnaya, 2003). The customer integrates resources in relational exchange with the service provider and other stakeholders in co-creating their service experience (Lusch et al., 2010; Payne, Storbacka, \& Frow, 2008).

Lastly, the customer co-creates value when consuming the service by applying unique customer resources in deriving value from using the service offering (Vargo \& Lusch, 2004). This process mostly takes place in the customer sphere (Grönroos \& Gummerus, 2014) and may include face-to-face interactions with other customers (Parker \& Ward, 2000) or online in social networks and communities (Grissemann \& Stokburger-Sauer, 2012). Parker and Ward (2000) suggest that customer-to-customer interaction is becoming an important area of research with the rise of SSTs and the delivery of services in non-employee environments. Parker and Ward (2000) identified that customers may play four roles during customer-tocustomer interactions, such as proactive help-seeker, reactive help-seeker, reactive helper and 
proactive helper. In the consumption process, the customer may undertake his or her value co-creation role in various ways which McColl-Kennedy et al. (2012) refer to as 'co-creation styles' in order to highlight the experiential and subjective nature of customer co-creation.

The roles assumed by customers in an SST-enabled service environment have received scarce attention. For example, there is a research gap with regard to customers' experiences and reflections in forced usage situations (Reinders et al., 2008) and in voluntary usage situations (Lawlor, 2010; Ritzer \& Jurgenson, 2010). Therefore, the present research follows Moeller et al.'s (2013) recommendation that further emphasis should be placed on the customer as creator of value, and also that the service provider and other customers be viewed as facilitators of that value creation. The S-D Logic proposes that value is always uniquely and phenomenologically determined and therefore, the customer experience and value creation are intertwined, whereby the social context, customer inner dialogue, and identities determine value creation (Helkkula \& Kelleher, 2010). An understanding of the customer perspective on their roles is even more necessary in an SST context where the customer not only evaluates the service outcome, but also co-produces the core service offering, thus determining the outcome (Hilton et al., 2013). In a tourism context, co-creation has been found to have a positive effect on customer satisfaction (Grissemann \& Stokburger-Sauer, 2012) and loyalty (Polo Pena et al., 2014), but the SST context may also introduce negative, value-destroying aspects (Hilton et al., 2013). Therefore, co-creation in SST usage in tourism requires specific research attention.

Furthermore, much of the value creation happens in the customer sphere which necessitates the understanding of the customer perspective on value co-creation (Gronroos, 2006; McCollKennedy et al., 2012). During SST encounters, customers actively participate in the delivery of the core service offering and thus determine the resulting service experience (Hilton et al, 
2013). Whilst the active role undertaken by customers during service encounters has been recognized in the services management and marketing literature (see for example Bitner et al., 1997; Lovelock \& Young, 1979; Mills \& Morris, 1986), the roles and functions assumed by the customer in an SST context requires further attention (Hilton et al., 2013).

\section{METHODOLOGY}

In order to explore the customer perspective on their SST role, this interpretivist research employs the existential philosophy of Schutz (1972). This philosophy promotes the understanding of human acts through a social interaction of exchanging words between a researcher and the actor who reflects on his or her experience of an activity (Schutz, 1972). In this research, the act relates to the customer's part in service delivery and consumption in an SST context, namely the role which he or she plays. Oberg (2010, p.990) describes a role as the "functions or activities performed by someone in the context of other actors".

The objective of the study was to examine tourist interactions with SSTs by exploring the roles that customers are required to play (i.e. forced usage) or invited to play (i.e. voluntary usage) in these SST encounters, in the context of value creation. Airline passengers who were awaiting their flights at an international airport in Ireland were selected as the sample for the study. Such participants would have had immediate experience of using SSTs at the point of travel (e.g. airport car park ticketing and entry, airline self-service check-in, use of mobile applications to check flight status), and recent experience of using SSTs, prior to travel (e.g. airline ticket booking, accommodation selection).

The decision to employ a qualitative approach was informed by the requirement to generate an understanding into the issue at hand rather than being concerned with measurement (Saunders, Lewis, \& Thornhill, 2009). A short qualitative interview format was the chosen 
method of data collection. This method is appropriate for gaining a broad perspective on marketing issues where little prior research is available (Carson, Gilmore, Perry \& Gronhaug, 2001; Wang et al., 2012). Short qualitative interviews quickly capture the main issues of a phenomenon and can be conducted closer to the time and place where the phenomenon takes place, compared with longer in-depth interviews (Wang et al., 2012). In the case of this research, access to the airport as a research setting was granted by the airport authority on the grounds that customers were not interviewed for periods longer than 10 minutes.

Short qualitative interviews were conducted with 133 airline passengers in the departure area of the airport, following a process of security screening and clearance for the interviewer. The participants were invited to talk about their SST usage for this trip and were then encouraged to discuss their experiences (positive or negative) with SSTs (see Appendix A for the interview theme sheet). The vast majority of passengers who were approached were welldisposed to participating in the research, citing their time availability whilst awaiting their flight and their overall interest in the research context. The interviews were conducted in the form of a natural dialogue between the interviewer and the participant, rather than a survey type question approach. This approach established a quick rapport, which was essential for eliciting reflective narratives in a short time. All interviews were recorded with the agreement of the participants, and transcribed, which is the recommended procedure for ensuring the quality of the data (King \& Horrocks, 2010).

Convenience sampling was employed leading to a broad sample in terms of ages, gender and education. The demographic characteristics of the convenience sample interviewed are presented in Table A1. The sample included participants travelling for business and leisure purposes, to and from Ireland. 
The interviews were analysed using an interpretive method of data analysis (Miles \& Huberman, 1994). This method of data analysis does not seek to uncover laws of causality, but rather to capture the essence of a participant's account and to understand the meaning of actions (Miles \& Huberman, 1994). The interpretive analysis included reading and re-reading of each transcript in order to understand whether an SST experience is positive or negative from the participant perspective and to what extent it represents value for the customer. The transcripts were then compared in terms of similarities in participants' perspectives on their actions. The emergent customer roles were interpreted and labelled by the authors. The analysis did not employ a predetermined, literature-based coding matrix, but rather allowed for the customer roles to emerge inductively. This analysis was aided by the qualitative data analysis software NVivo 9. The interpretation was validated by performing a critical analysis (Daymon \& Holloway, 2011). Critical analysis is based on evaluating how clearly the interpretation is supported by the data and analysis of any negative cases which disconfirm the conclusions. The next section presents the findings relating to the nature of the SST customer roles which the authors interpreted from the participants' accounts of their SST experiences.

\section{FINDINGS}

As previously discussed, the interviews commenced by inviting participants to reflect on SSTs that they had used with regard to their travel arrangements. The passengers volunteered a wide range of SST interfaces, including kiosks, websites accessed via PC or mobile devices, mobile applications, voice response telephone menus, headphones and interactive guides at travel attractions. The interpretive analysis of the short qualitative interviews provided numerous situations when participants reflected on their experiences and activities during SST usage. Those reflections were then examined in terms of the apparent roles assumed by customers in SST encounters. The analysis identified six roles that customers 
undertake, namely the customer as a convenience seeker, motivated worker, judge, enforced worker, unskilled worker and assistance provider. These roles will be examined below in turn, accompanied by sample excerpts from the interviews. The excerpts are labelled with unique codes that correspond to interview participants. For example, 'Int.28.M' identifies interviewee number 28 who was a male participant.

\section{Convenience Seeker}

The first customer SST role identified in this study is that of a convenience seeker. The data analysis indicates that a convenience seeker actively embraces SSTs which provides him or her with expediency, lower prices, enjoyment, and control, but the customer is not required to provide excessive inputs. Convenience seekers use the SST interface in an effortless manner and with a functional motive to obtain more efficient and speedy service. The nature of this role is illustrated in the excerpt below where the customer refers to the ease with which he can generate airline boarding passes via a SST:

Recently, I've started using the electronic boarding passes. I frequently fly between Zurich and London...I can download the boarding pass on to my iPhone beforehand and then when I get to the airport, I just hold my iPhone under the scanner. You don't need to print anything, you don't need to go to the desk to pick up your boarding pass, so it saves time, and it means you have one less item to carry. It's quite handy. (Int.80.M)

In this case, the customer role is one of doing as little as possible to obtain a very efficient service. This participant's perspective is observable in expressions such as "I just hold my iPhone" and highlighting how much the customer "does not need to do" to get the service.

When SST users undertake the convenience seeker role, they seek hassle-free, effortless service encounters. The emotional representation of this role is a feeling of accomplishment, independence and competence, as illustrated by the following excerpt: 
...once I check-in for an airline, you have the freedom to check in at any time, whereas if you do it physically, one, you are queuing up, two, you have a shorter window to actually check in, and then if you use online you can really cut it down to moments before the gate closes to arrive at the airport. (Int.35.F)

The sense of freedom and accomplishment alluded to here, is indicative of the value accruing from the use of the SST, with minimum effort to this customer.

\section{Motivated Worker}

The second customer role, namely the motivated worker, represents the customer view that SST usage requires "work" on the part of the customer, which is either in return for control or price benefits, or else it is "just the way things are done". The difference to the previous convenience seeker role is that in a motivated worker role, participants displayed a highlighted perception that they had a responsibility to contribute to effective service delivery, that is to say, act as workers, as opposed to engaging in minimum effort, which was evident in the convenience seeker role. This responsibility included providing the required customer inputs and co-operating with the service provider where needed, as is evident in the following excerpt:

You need to learn how to use it [SST]...[then] you will have no problems with checkin services, and you need to learn how to read the fine print, as well. Especially with [airline X], because if you didn't read that your bag needs to be under a certain weight, or under certain dimensions as well, then you'd have another €40 bill on top of it. (Int.79.F)

In this excerpt, the motivated worker takes her responsibilities seriously when using SSTs. In this role, customers will double-check their inputs and do everything within their abilities to contribute to the SST delivery. For example, the example below illustrates how the participant was motivated to engage with the SST in what she perceived was the correct manner, when booking airline tickets online:

I said to [husband's name], "Go back and check, go back and check, make sure we got the right site page open!" So, I would be a bit nervous like that... Because if you make a mistake, you make a mistake and it is your own mistake online... I like double- 
checking, making sure that I have the right date, the right venue, dates and so on... (Int.70.M)

This excerpt indicates this participant's desire to avoid any mistakes and service failures. In general, the motivated worker displays a clear understanding that they "have work to do" in order to reap key service benefits, such as a lower price or increased control. To that end, they are prepared to undertake specific tasks carefully and assiduously.

\section{Judge}

The third customer role is that of the judge. Customers may assume the role of a judge when they assess the SST encounter, either in a positive or negative manner, and possibly provide suggestions for improvement to the company in question.

For example, the judge role was evident when participants compared their experience of one company's SST with a similar SST from another company. This knowledge gave them confidence to benchmark SSTs, as may be evidenced below where a participant compared the SSTs of two airlines:

...we are then connecting using [airline $\mathrm{Y}$ ] and their self-service technologies are more advanced than the likes of [airline X], and it is easier to do it. (Int.5.M)

In the role of a judge, customers not only evaluate the SST processes, but may also provide recommendations and feedback to the company. At times, in the judge role, participants engage in "consulting" with the company about faults in the service. In this respect, the following excerpt suggests that for some technologically proficient customers, it is a matter of benevolence towards the service company:

I used to be in the technology industry, so when I see something that I think is ridiculous or redundant, I would usually shoot them up a quick note saying... this stuff doesn't work right, you should do it this other way. (Int.58.M)

On the other hand, the negative judge role that a customer may assume was evident in one participant's experience with a website's terms and conditions section. This participant 
criticized the lengthy document that customers had to read and expressed his opinion as to how the information should be presented:

As a customer, it is not possible for us to go through...six pages of rules and regulations. Probably you have seen that even for the flight, you may get the rules, five to six pages. And I don't think [any] of us knows what exactly it is... Probably there should be around 10-15 key points...they can provide the six pages, but they should provide the key points [regarding] what exactly we should know as a customer. (Int.10.M)

It is observed from the above extracts that these customers are keen to engage in assessing their SST experiences and frequently appraise the company of same, with a view to assisting the company to improve the SST encounter, for themselves and future customers.

\section{Enforced Worker}

The fourth customer role which was identified in this research is that of the enforced worker.

The difference between the motivated worker and the enforced worker is their relative willingness to participate in the SST encounter. The enforced worker role reflects the customer self-description of having to provide inputs towards using SSTs unwillingly and because of no other perceived alternative, whereas the motivated worker is enthusiastic and willing to engage in SST service. The nature of the enforced worker role is illustrated by the following interview excerpt whereby the participant suggests that the airline requires customers to check in online:

Unfortunately, I am travelling with [airline X] today....which are a very tough airline to work with, as a result we needed to print our boarding passes yesterday. That involved having to go to an internet cafe and that really added a lot of stress to the situation...they require you as an airline to do it all online beforehand otherwise they charge you additionally. So, it makes sense to do as much as you can. (Int.5.M)

Therefore, he has no choice, but "to do the aspects of the work" if he wants to fly with this airline. A prevalent view relating to the enforced worker role is that the service provider dominates the service process design and customers are in a position only to accept the 
service provider decisions. For example, one participant referred to the responsibilities being imposed on him, concluding that he was ultimately assuming the role of an employee when booking online:

So, they [airline] surcharge you really for doing their work. You are booking in, you are taking the place of a staff member, you are doing it all for them, and it takes you half an hour maybe of your time, by the time you put in all the information, serial numbers and passports. (Int.89.M)

Customers in the enforced worker role often described negative emotions such as annoyance, unfairness, and pressure. Indeed, the following participant is resigned to the fact that customers need not only to learn to use the technology but also be prepared to accommodate developments in technology:

Everybody is on the internet now... and you have to like it, you have to move with the times. (Int.33.F)

It is apparent from the above findings that customers accept being forced into SST usage by the service provider, but there is an element of reluctance and resignation. Equally, it is observed that these customers may also enforce SST usage on themselves because they perceive that they will be at a bigger disadvantage otherwise.

\section{Unskilled Worker}

The fifth customer role which emerged in the research is the unskilled worker. Customers who undertake an unskilled worker role generally possess the same views as the motivated worker, but they perceive their own technological knowledge and activities as insufficient to get the "work done" successfully. Thus, they recognize that the shortcoming is on their part, in terms of a shortage of information technology (IT) skills, SST operational knowledge or physical disabilities which prevented them from effective usage of the SST. For this reason, they may need to try harder or seek assistance from other customers, or the company: 
Well, you would be a bit fearful at the start, you know, just in case you booked something that you don't want or it's the wrong date...you are constantly checking...are you doing the right thing? There is a bit of learning involved. (Int.63.F)

My trip to Ireland, my husband booked it for me on the internet. He is much quicker than I am. (Int.109.F)

Some customers volunteered that their inability to operate the technology could be the result of age or a disability. The excerpt below illustrates how the participant describes himself as an unskilled worker because he finds it "difficult" to keep up with the instructions and complete the service:

It is a bit difficult for me. When I was going to school there was only Abacus. [smiling] I do find it difficult. [When booking online] they say: "You've got to hurry up with this now because you will be clocked out". And if I don't go fast enough, I get timed out and I have to restart again. (Int.8.M)

Other participants may resort to seeking help from others to make up for their lack of technological skills. This illustrates a dimension of the unskilled worker role, namely that of help-seeker. A participant booked her overall trip online with the help of a "friend from work... I had to get somebody else to help me, because I am not able to do it”. (Int.10.F). Furthermore, unskilled workers may have availed of the help of company employees when they were available, as illustrated by a participant when trying to check-in via an airport kiosk:

It was at [X airport] itself. And one of the [employees] just came and...did it all very quickly for me. But I am sure, if I'd had my glasses on and I just took my time, I'd have done it...Because it is very easy, all you have to do is read it, they give you instructions. So, it's very easy really. But the glasses were somewhere in the bag and I couldn't, you know, hold everyone up looking for them. So, I thought, this nice young lady will help me. (Int.109.F)

This example is indicative of the unskilled worker role that this participant undertook because she could not physically see the instructions on the check-in kiosk. She also suggested the tension in this customer role when other customers were present at the service site, namely "I couldn't, you know, hold everyone up". It is noticeable from the discussion of the unskilled 
worker so far that unlike all other roles, customers in this role may often refer to their age or age-related abilities, or their perceived lack of personal, technological savoir faire. The social interaction aspect of looking for help may be associated with pleasant exchanges. However, in the role of unskilled worker, participants may also feel embarrassment and social tension, particularly when they are affecting the quality of the service for other customers.

\section{Assistance Provider}

The sixth customer role is that of an assistance provider whereby as alluded to above, some customers may assist others with SST tasks. These experienced customers may engage in assisting others out of empathy or obligation. Participants described themselves as providing help enthusiastically or reluctantly to fellow customers; hence, the authors suggest the following labels: enthusiastic assistance provider and reluctant assistance provider. The enthusiastic assistance provider role may be evidenced in the excerpt below suggesting a positive attitude towards helping others:

Actually in airports as well, when people don't know how to use the check-in machine, you would give someone a hand, you know, people often ask and things like that. Usually where there are automated machines, especially if someone was older, you know, there is often confusion, so you would, you'd help. (Int.63.F)

It becomes evident from the assistance provider role that the perception of age had an implication for this customer SST role. The assistance provider role was undertaken with less hesitation when directed towards an elderly person. For example:

Obviously, I am [from a] younger generation. Maybe [the] older generation...don't like to use it maybe so much. They are not so confident with it, I think...I don't mind helping. I think it is quite nice just to help people if they need [it]. It is a good experience. (Int.28.M)

Such an approach is indicative of a positive and altruistic mind-set towards providing assistance to others. This is in contrast to the hesitation and social tension which may occur 
when a helper is deciding whether to approach a customer in need of assistance as identified in the excerpt below:

Well, like, you might gauge... Some people if they need help, like, they will be throwing up eyes, "Somebody, come help me!" And other people, they will just be [expletive], screaming and shouting and...if you do go near them, they will be like: "Get away!" (Int.38.M)

The above description is suggestive of reluctance on the part of the experienced SST user to assist others; hence, the "reluctant assistance provider" title for this role. The customer in a reluctant assistance provider role will help others if necessary but may be less than eager at having to do so. For example, a participant appeared to be somewhat reluctant to engage in an assistance provider role, as may be evidenced by the following excerpt:

They were struggling with the online check-in kiosk. I think, he was German, himself and his wife and two kids and I helped them check-in which is quite strange considering it's not a service passengers offer, I mean, you would have thought that there would be someone from the airline helping them. But there was no one around. (Int.35.F)

Depending on the customer perceptions of their activities in the service situation, customers may undertake a blend of SST roles or change from one role into another during the course of the service encounter. In the following section the findings and their implications for research and SST service management will be discussed.

\section{DISCUSSION}

Whilst the role of the customer has been extensively examined in the broader service context (see for example; Bitner et al., 1997; Chervonnaya, 2003; Moller et al., 2013), the roles assumed by customers in an SST context have not been identified (Hilton et al., 2013). The findings from this research suggest that SST customers undertake a variety of roles in a tourism context, namely convenience seeker, judge, motivated worker, enforced worker, unskilled worker, and assistance provider. These roles reflect the customer perceptions of 
their co-creation interactions in SSTs and contribute to the S-D Logic framework by providing a deeper understanding of co-creation in a specific service context. The customer roles identified in SSTs are rather different to the roles identified in other service settings (e.g. McColl-Kennedy et al., 2012), which is in line with the S-D Logic's emphasis on the variations in service contexts. From an S-D Logic perspective, customer roles represent not only observable and unobservable activities in service (Chervonnaya, 2003), but also the customer's phenomenological experience of co-creation.

The roles can broadly be divided into "voluntary" roles, that is to say "I choose to do", which reflects a customer-dominance perspective, or enforced roles, that is to say "I am required to do" which reflects a provider-dominance perspective. The variety and the richness of these roles reflect the S-D Logic which suggests that value is uniquely and phenomenologically cocreated and determined by the customer (McColl-Kennedy et al., 2012; Vargo \& Lusch, 2008). Indeed, the SST customer roles bear some similarities with the general customer roles from the literature, but they introduce specific nuances providing a deeper understanding of the various ways in which customers co-create in SSTs.

For example, a convenience seeker can be compared to the roles of contributor to quality, satisfaction, and value, as suggested by Bitner et al. (1997), decision-maker and hunter (Chervonnaya, 2003), and bargain-hunting independent and self-reliant customizer (Moeller et al., 2013). Even so, the convenience seeker role does not only broadly state that customers make decisions and contribute to the service, but it specifies that SST users seek out convenience, and then enhance their decision by highlighting how much more convenient the SST option is in comparison with other service channels. In the role of a motivated worker, customers perceive that they are skilled to undertake their production role in return for service benefits while in the role of an unskilled worker; they perceive that they are not 
sufficiently skilled, and therefore often require assistance from employees or other customers. The role of an enforced worker reflects a perspective that the customer is being overly dominated by the service provider and is being "forced" into undertaking unwanted responsibilities in SST delivery. All of the above three worker roles are reminiscent of the partial employee (Mills \& Morris, 1986), ingredient (Chervonnaya, 2003), or productive resource (Bitner et al., 1977) roles, but are more specific regarding the effect that customers may undertake to fulfil service provider instructions in order to contribute to service production.

The judge role can assume a positive or negative guise. When performing a positive judge role, customers perceive that they are competent to provide an expert opinion about the service, and they communicate feedback to the service provider. In this role, customers may even generate creative solutions to problems with the service. In the role of a negative judge, customers focus on criticizing the service without providing any constructive contributions towards service improvements. The judge role in this research may be compared in a limited manner to the roles of an innovator (Graf, 2007), marketer (Chervonnaya, 2003), consultant (Ford \& Heaton, 2001), quality control inspector (Ford \& Heaton, 2001), auditor (Chervonnaya, 2003), source of competence (Graf, 2007), and instructor (Chervonnaya, 2003). The judge role differs from these other examples as it highlights the provision of a judgement which seeks to improve the service. The negative judge displays a unique perspective of being personally critical of the service, but creates no value either for the company or for the customer. When considered in the context of S-D Logic, the role of SST judge is a key finding in this research because it acknowledges the role of the customer not just as a creator of value in the immediate SST encounter, but also in terms of collaborating with the provider to improve the SST in the long term by way of sharing personal experiences and recommendations. 
The SST role of an assistance provider (either enthusiastic or reluctant) reflects SST users who assist fellow customers. This role may be compared to the general customer service roles of helper (Parker \& Ward, 2000) and trainer of employees and other customers (Ford \& Heaton, 2001). The reactive and proactive helper roles (Parker \& Ward, 2000) bear some similarity to the reluctant and enthusiastic assistance provider roles in the present study. For example, an enthusiastic or a reluctant assistance provider may be a reactive or a proactive helper. A reluctant assistance provider in this research may proactively, but unwillingly, provide assistance to another customer who is preventing or delaying the former from using an SST. Alternatively, an enthusiastic assistance provider may be a reactive helper in terms of actively watching for clear signs that another customer requires assistance in situations where social interaction may otherwise be interpreted as an invasion of privacy, such as banking automated teller machines (ATMs). This distinction is necessary in an SST context where customers may have to help others use an SST in order to gain access to it themselves.

However, when viewed against S-D Logic, it could be argued that when a service provider limits or removes customer access to employee assistance (e.g. if they are having difficulties), the provider is essentially gaining value from the assistance-providing customers, who act as unpaid workers (see for example Tapscott \&Williams, 2006). As such, a key contribution of the present study is to highlight the ethical consideration that may arise when service providers assume that customers will either be technologically proficient, or if not, may rely on the assistance of other customers. Such providers will have to arrive at a delicate balancing act between nurturing and not exploiting this "tap of human kindness", to adapt a phrase from Nambisan and Baron (2009).

The distinction of six SST roles reveals that SST users do not always perceive their role as co-creating service benefits for themselves. The exploration of the customer perspective also 
reveals a contradictory view of working for (enforced worker) and on behalf of (assistance provider) the company even when not prepared for SST usage (unskilled worker). Therefore, it may be inferred that the SST user may at times forgo their own usage agenda (e.g. personal convenience) for the benefit of the overall service operation and other stakeholders (other customers, company and employees). In the SST context, customers view their roles as responsible co-producers in a service system of providers, other customers, employees, and technology, where the SST user is not always in the role of a consumer of the service. In an enforced worker role and an assistance provider role, the SST user suggests that when using the SST, they are not consumers of a service, but rather workers for the service company. This perspective challenges the customer centricity of the S-D Logic and the proposition that value is co-created only in consumption. This is a key contribution of this research resulting from the specific SST context.

The enforced worker role represents a significant finding which challenges previous SST research findings that when customer choice is reduced, customers will develop switching intentions (e.g. Liu, 2012; Reinders et al., 2008). The enforced worker role depicts a perspective that the customer has no choice but to engage in SST usage which is imposed on him or her. Therefore, the customer does not choose to create the experience with the service provider (co-creator) or is invited by the service provider to take part in co-production (partial employee), but rather the customer is pressurized into service production. This perspective on the customer role as being pressurized is not conceptualised in the literature, and is a unique finding specific to the customer roles in SSTs.

The six roles also suggest that in an SST situation, the customer is always a central producer, but is not always a consumer. This conclusion has implications for SST implementation strategies. Customers demonstrate awareness that they contribute to service delivery when 
they use SSTs and facilitate the service provider to realise cost savings. In an enforced worker role, SST users suggest that the service company is not appreciative of customer contributions to service delivery, and may be unnecessarily inconveniencing customers by asking them to use SSTs. These negative perceptions may be alleviated by implementing procedures which recognise the customer as a partner in service production. Service providers may periodically thank their customers for co-operating in SST usage, helping the company to deliver better service and improving the well-being of society. Regular tokens of appreciation may help build a better relationship with the customer and even elicit valuable feedback and suggestions from customers. Indeed, in this study, customers in a judge role expressed negative perceptions when the service provider disregarded their feedback or suggestions to improve the service process. Therefore, a key recommendation for SST providers is to recognise and appreciate SST users not as "partial employees" or "consumers", but as stakeholders who may often have to oblige the company and facilitate its production processes. This approach will help create harmony in the customer-company relationship by returning the goodwill extended by the customer toward the company when they use SSTs.

The findings reveal that some customer roles in this research contribute positively to value creation (i.e. convenience seeker, motivated worker, judge, enthusiastic assistance provider), while others may contribute negatively to value creation (i.e. enforced worker, unskilled worker, reluctant assistance provider). Thus, the authors propose that customer experiences can be placed on a continuum from positive to negative in relation to these customer roles. Figure 1 presents this role-experience continuum. 
Figure 1. Role-Experience Continuum

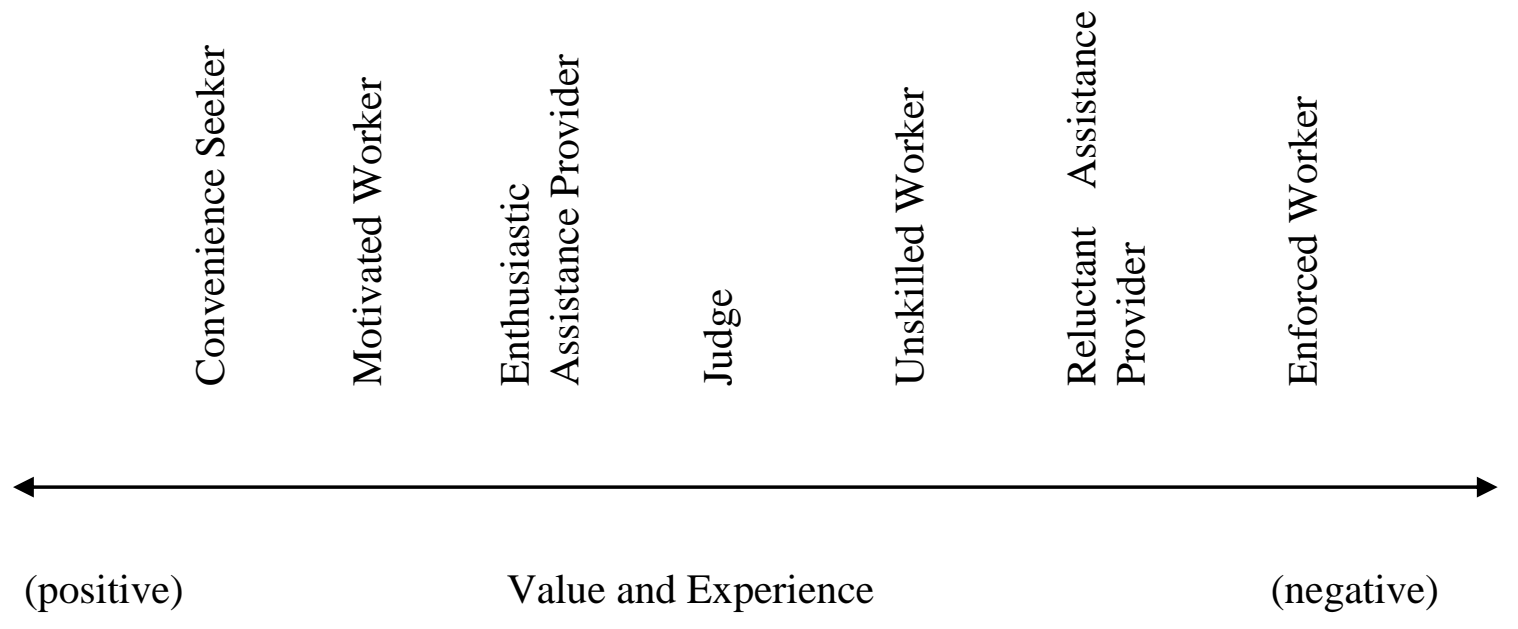

Source: The Authors

The representation of customer roles as value-creating and value-destroying has conceptual significance because they require different management and facilitation. With the exception of McColl-Kennedy et al. (2012), the service roles literature suggests that customers may have positive or negative experiences depending on their level of skills and motivation to undertake an agreed service roles script (see for example, Bitner et al., 1997; Chervonnaya, 2003). The present study reveals that customers may not only undertake a role successfully or unsuccessfully, but they may undertake roles which are inherently value-creating or valuedestroying. This perspective suggests that the service provider should not focus on how to train customers to follow a general service script efficiently, but on how to transform them from value-destroying to more value-creating roles on the role-experience continuum. This perspective on customer roles provides infinitely more scope for co-creating value with the 
customer, than merely training customers to achieve the operating standards set out by the service provider (e.g. Mills \& Morris, 1986).

For example, when in the role of an unskilled worker, the user perceives that their role is that of someone who is not able to interact with the SST effectively. This perception may be changed by communicating and creating SST usage scalability to match these customers' skills. This change in perceptions may transform these customers into motivated workers who will create more value-enhanced experiences. Companies may proactively assist such customers in learning, by teaching and helping them so that the perceptions of being unable to engage with the SST are reduced. Some websites may have monitoring facilities which alert a company employee to engage via online chat with a customer who appears to have difficulties. Furthermore, if an SST kiosk is part of a service process where online booking is completed first, such as kiosk check-in at airports, the company website may provide $a$ priori instructions or demonstrations regarding their kiosk operation.

\section{CONCLUSION}

This paper explored the customer perspective on their SST usage and defined six user roles. These roles contribute to the S-D Logic framework by extending the knowledge on cocreation in a specific service context. The S-D Logic places importance on the understanding of co-creation in context (Akaka et al., 2015). As examined earlier, customer roles have primarily been identified as general roles in the service management literature, but their specific roles in SST encounters have not been identified. Through the lens of the S-D Logic, general customer roles are specific and nuanced roles, which are relevant to the tourism SST context. 
The S-D Logic (Vargo \& Lusch, 2008) views the customer as being a co-creator of value and it is the customer who ultimately determines the value in the service experience. In such a cocreation partnership, it is important to ascertain and balance the interests of both the company/service provider and the customer, as both parties ask themselves: "What's in it for me?" However, the literature has focused on the concept of the customer working "for" the company, that is to say, as a partial employee (Mills \& Morris, 1986). To follow S-D Logic, the customer as a co-creator and equal partner in the service relationship will bring their own specific requirements and demands such as time savings, convenience and control to the SST encounter. Therefore, a significant contribution of this research is to highlight the roles reflecting the creation and delivery of value by the customer in the SST encounter.

In terms of the significance of these findings to service providers, the findings from this research may give ground for further planning of SST design features and marketing activities. Service providers may have to evaluate how each of these roles may be undertaken in the context of their own service offering. Rather than segmenting their customers in terms of geographic (e.g. Dean, 2008) and psychographic characteristics (e.g. Lee et al., 2010; Meuter et al., 2005), SST service managers may also approach their service planning in terms of the six roles identified in this research. For example, the unskilled worker role may be characterised by lack of time and attendant feelings of tension and inadequacy, if customers are experiencing SST difficulties in a public place, and are therefore inconveniencing other customers queuing behind them.

This research has certain limitations which should be considered when determining its scope. The desire to capture a multitude of perspectives first hand from a diverse demographic sample of participants justified the choice of an airport as the research location. A drawback to this approach is that there was a limitation to the length of the interviews and 
correspondingly the depth of the discussion. Longer in-depth interviews could provide an opportunity to build a more complete and richer description of the SST customer roles. Furthermore, the factors, motivations and experiences associated with each role require a more in-depth exploration and identification of possible connections and interdependencies.

\section{References}

Akaka, M.A., Vargo, S.L., \& Schau, H.J. (2015). The context of experience. Journal of Service Management, 26 (2), 206 - 223. http://dx.doi.org/10.1108/JOSM-10-2014$\underline{0270}$

Baron, S., Patterson, A., \& Harris, K. (2006). Beyond technology acceptance: understanding consumer practice. International Journal of Service Industry Management, 17(2), 111-35. http://dx.doi.org/10.1108/09564230610656962

Bitner, M., Faranda, W., Hubbert, A., \& Zeithaml, V. (1997). Consumer contributions and roles in service delivery. International Journal of Service Industry Management, 8(3), 193205. http://dx.doi.org/10.1108/09564239710185398

Bitner, M., Ostrom, A., \& Meuter, M. (2002). Implementing successful self-service technologies. Academy of Management Executive, 16(4), 96-108. DOI: 10.5465/AME.2002.8951333.

Carson, D., Gilmore, A., Perry, C., \& Gronhaug, K. (2001). Qualitative marketing research, London: Sage.

Chervonnaya, O. (2003). Customer role and skill trajectories in services. International Journal of Service Industry Management, 14(3), 347-63. http://dx.doi.org/10.1108/09564230310478864

Collier, J.E., \& Kimes, S. (2013). Only if it is convenient: Understanding how convenience influences self-service technology evaluation. Journal of Service Research, 16(1), 39-51. DOI: $10.1177 / 1094670512458454$.

Collier, J.E., Moore, R.S., Horky, A., \& Moore, M.L. (2015). Why the little things matter: exploring situational influences on customers' self-service technology decisions. Journal of Business Research, 68, 703-710. DOI: 10.1016/j.jbusres.2014.08.001.

Dabholkar, P., \& Bagozzi, R. (2002). An attitudinal model of technology-based self-service moderating effects of consumer traits and situational factors. Journal of the Academy of Marketing Science, 30(3), 184-201. doi: 10.1177/0092070302303001

Daymon, C. and Holloway, I. (2011) Qualitative research methods in public relations and marketing communications, Second Edition, London: Routledge. 
Dean, D. (2008). Shopper age and the use of self-service technologies. Managing Service Quality, 18(3), 225-38. http://dx.doi.org/10.1108/09604520810871856

Edvardsson, B., Ng, G., Zhi Min, C., Firth, R., \& Yi, D. (2011). Does service-dominant design result in a better service system?, Journal of Service Management, 22(4), 540-56. http://dx.doi.org/10.1108/09564231111155114

Elliott, K., Hall, M., \& Meng, J. (2013). Customers' intention to use self-service technology: The role of technology readiness and perceptions towards self-service technology. Academy of Marketing Studies Journal, 17(1), 129-43.

Ford, R., \& Heaton, C. (2001). Managing your guest as a quasi-employee, Cornell Hotel and Restaurant Administration Quarterly, April, 46-55. doi:10.1016/S0010-8804(01)80038-0

Gelderman, C., Ghijsen, P., \& Diemen, R. (2011). Choosing self-service technologies or interpersonal services - The impact of situational factors and technology-related attitudes. Journal of Retailing and Consumer Services, 18(3), 414-21. DOI: 10.1016/j.jretconser.2011.06.003

Graf, A. (2007). Changing roles of customers: Consequences for HRM, International Journal $\begin{array}{llll}\text { of Services Industry } \quad \text { Management, } & \text { 18(5), }\end{array}$ http://dx.doi.org/10.1108/09564230710826269

Grissemann, U.S., \& Stokburger-Sauer, N.E. (2012). Customer co-creation of travel services: The role of company support and customer satisfaction with the co-creation performance. Tourism Management, 33(6), 1483-1492. doi:10.1016/j.tourman.2012.02.002

Grönroos, C. (2006). Adopting a service logic for marketing. Marketing Theory, 6(3), 317333. doi: $10.1177 / 1470593106066794$

Grönroos, C., \& Gummerus, J. (2014). The service revolution and its marketing implications: Service logic vs service-dominant logic, Managing Service Quality, 24(3), 206-29. DOI: 10.1108/MSQ-03-2014-0042.

Helkkula, A., \& Kelleher, M. (2010). Circularity of customer service experience and customer perceived value. Journal of Customer Behaviour, 9(1), 37-53. http://dx.doi.org/10.1362/147539210X497611

Helkkula, A., Kelleher, C., \& Pihlstrom, M. (2012). Characterizing value as an experience: Implications for service researchers and managers. Journal of Service Research, 15(1), 5975. DOI:10.1177/1094670511426897

Hilton, T., Hughes, T., Little, E., \& Marandi, E. (2013). Adopting self-service technology to do more with less. Journal of Services Marketing, 27(1), 3-12. http://dx.doi.org/10.1108/08876041311296338

Kelly, P., Lawlor, J., \& Mulvey, M. (2011). A review of key factors affecting consumers' adoption and usage of self-service technologies in the tourism sector. In K. O'Connell, M. Palma Fahey, S.T. Ruane, \& K. Horan, (Eds.) Tourism and hospitality research in Ireland: Current challenges and future opportunities. NUI Galway and Shannon College of Hotel Management. 
King, N., \& Horrocks, C. (2010). Interviews in qualitative research, London: Sage.

Lawlor, J. (2010). The role of the consumer as a quasi-employee in service organizations: A research agenda. In G. Gorham, \& Z. Mottiar (Eds.) Contemporary issues in Irish and global tourism and hospitality. Dublin: Dublin Institute of Technology.

Lee, W., Castellanos, C., \& Choi, H.S.C. (2012). The effect of technology readiness on customers' attitudes toward self-service technology and its adoption; The empirical study of U.S. airline self-service check-in kiosks. Journal of Travel and Tourism Marketing, 29(8), 731-743. DOI: 10.1080/10548408.2012.730934

Lee, H., Cho, H., Xu, W., \& Fairhurst, A. (2010). The influence of consumer traits and demographics on intention to use retail self-service checkouts. Marketing Intelligence and Planning, 28(1), 46-58. http://dx.doi.org/10.1108/02634501011014606

Lin, J., \& Chang, P. (2011). The role of technology readiness in self-service technology acceptance. Managing Service Quality, 21(4), 424-44. http://dx.doi.org/10.1108/09604521111146289

Liu, S. (2012). The impact of forced use on customer adoption of self-service technologies. Computers in Human Behavior, 28, 1194-1201. http://dx.doi.org/10.1016/j.chb.2012.02.002

Lovelock, C., \& Young, R. (1979). Look to consumers to increase productivity. Harvard Business Review, May-June, 168-78.

Lusch, R., Vargo, S., \& Tanniru, M. (2010). Service, value networks and learning. Journal of the Academy of Marketing Science, 38, 19-31. DOI:10.1007/s11747-008-0131-z

Matthing, J., Sandén, B. \& Edvardsson, B. (2004). New service development: learning from and with customers, International Journal of Service Industry Management, 15(5), 479 - 498. http://dx.doi.org/10.1108/09564230410564948

McColl-Kennedy, J., Vargo, S., Dagger, T., Sweeney, J., \& Kasteren, Y. (2012). Health care customer value co-creation practice styles. Journal of Service Research, 15(4), 370-89. DOI: $10.1177 / 1094670512442806$.

Meuter, M., Bitner, M., Ostrom, A., \& Brown, S. (2005). Choosing among alternative service delivery modes: An investigation of customer trial of self-service technologies. Journal of Marketing, 69(2), 61-83. http://dx.doi.org/10.1509/jmkg.69.2.61.60759

Miles, M., \& Huberman, M. (1994). Qualitative data analysis, 2nd ed. Thousand Oaks, CA: Sage.

Mills, P., \& Morris, J. (1986). Clients as 'partial' employees of service organizations: Role development in client participation. Academy of Management Review, 11(4), 726-35. DOI: 10.5465/AMR.1986.4283916.

Moeller, S., Ciuchita, R., Mahr, D., Odekerken- Schroeder, G. \& Fassnacht, M. (2013). Uncovering collaborative value creation patterns and establishing corresponding customer roles. Journal of Service Research, 16(4), 471-87. DOI: 10.1177/1094670513480851. 
Nambisan, S., \& Baron R.A. (2009). Virtual customer environments: Testing a model of voluntary participation in value co-creation activities. The Journal of Product Innovation Management 26 (4), 388-406. DOI: 10.1111/j.1540-5885.2009.00667.x

Oberg, C. (2010). Customer roles in innovations. International Journal of Innovation Management, 14(6), 989-1011.

Parker, C., \& Ward, P. (2000). An analysis of role adoptions and scripts during customer-tocustomer encounters. European Journal of Marketing, 34(3/4), 341-58. http://dx.doi.org/10.1108/03090560010311894

Payne, A.F., Storbacka, K., \& Frow, P. (2008). Managing the co-creation of value. Journal of the Academy of Marketing Science, 36(1), 83-96. DOI 10.1007/s11747-007-0070-0

Polo Peña, A.I., Frías Jamilena, D.M., \& Rodríguez Molina, M.A. (2014). Value co-creation via information and communications technology. The Industries Journal of Service, 34(13): 1043-1059. DOI: $10.1080 / 02642069.2014 .939641$

Reinders, M., Dabholkar, P., \& Frambach, R. (2008). Consequences of forcing consumers to use technology-based self-service. Journal of Service Research, 11(2), 107-23. DOI: $10.1177 / 1094670508324297$

Ritzer, G., \& Jurgenson, D. (2010). Production, consumption, prosumption: The nature of capitalism in the age of the digital 'prosumer'. Journal of Consumer Culture, 10(1), 13-36. DOI: $10.1177 / 1469540509354673$.

Roberts, D., Hughes, M., \& Kertbo, K. (2013). Exploring consumer's motivations to engage in innovation through co-creation activities. European Journal of Marketing, 48(1/2), 147169. http://dx.doi.org/10.1108/EJM-12-2010-0637

Rosenbaum, M. \& Wong, I. (2015). If You install it, Will they use it? Understanding why hospitality customers take 'technological pauses' from self-service technology. Journal of Business Research, 68(9), 1862-68. doi:10.1016/j.jbusres.2015.01.014

Saunders, M., Lewis, P., \& Thornhill, A. (2009). Research methods for business students. Harlow: Financial Times Prentice Hall.

Schutz, A. (1972). Phenomenology of the social world, Illinois: Northwestern University Press.

Shaw, G., Bailey, A., \& Williams, A. (2011). Aspects of service-dominant logic and its implications for tourism management: Examples from the hotel industry. Tourism Management, 32, 207-214. doi:10.1016/j.tourman.2010.05.020

Simon, F., \& Usunier, J. (2007). Cognitive, demographic, and situational determinants of service customer preference for personnel-in-contact over self-service technology. International Journal of Research in Marketing, 24(2), 163-73. DOI: 10.1016/j.ijresmar.2006.11.004.

Tapscott, D. \& Williams, A. (2006). Wikinomics: How mass collaboration changes everything, New York, NY: Portfolio. 
Vargo, S., \& Lusch, R. (2004). Evolving to a new dominant logic for marketing. Journal of Marketing, 68 (January), 1-17. http://dx.doi.org/10.1509/jmkg.68.1.1.24036

Vargo, S., \& Lusch, R. (2008). Service dominant logic: continuing the evolution. Journal of the Academy of Marketing Science, 36, 1-10. DOI 10.1007/s11747-007-0069-6

Wang, C., Harris, J., \& Patterson, P. (2012). Customer choice of self-service technology: The role of situational influences and past experience. Journal of Service Management, 23(1), 5478. http://dx.doi.org/10.1108/09564231211208970

\section{Appendix A}

\section{Theme Sheet}

SSTs are technologies which allow you to access a service yourself, without the help of a company employee. Examples include banking ATMs, websites for booking online, search engines for price comparison, online check-in for your flight, and selling on eBay.

1. For the purpose of this trip, what SSTs did you use?

2. What other SSTs are you a user of?

3. How did you feel about using those SSTs?

4. Can you think of an example, or a particularly memorable experience (positive or negative) with an SST? Tell me about it.

Demographic Information

1. Gender

male/female

2. In which of the following groups does your age fall?

$18-24 \quad 25-34 \quad 35-44 \quad 45-54 \quad 55-64 \quad 65+$

3. Educational level achieved (please indicate the highest level achieved to date)

primary education high school bachelor degree postgraduate degree

4. Nationality 


\section{Appendix B}

Table 2 Demographic Characteristics of the Sample

\begin{tabular}{|c|c|c|c|c|c|c|c|c|}
\hline Gender & $\begin{array}{l}\text { Age } \\
\text { (years) }\end{array}$ & Age no & Age \% & Education & $\begin{array}{l}\text { Education } \\
\text { no }\end{array}$ & $\begin{array}{l}\text { Education } \\
\%\end{array}$ & Nationality & $\begin{array}{l}\mathrm{Na} \\
\text { no }\end{array}$ \\
\hline \multicolumn{9}{|l|}{ Male } \\
\hline 69 & $18-24$ & 14 & $20.29 \%$ & Primary & 1 & $1.45 \%$ & IRL & 31 \\
\hline \multirow[t]{8}{*}{$51.88 \%$} & $25-34$ & 16 & $23.19 \%$ & High School & 25 & $36.23 \%$ & UK & 14 \\
\hline & $35-44$ & 11 & $15.94 \%$ & $\mathrm{BA}$ & 23 & $33.33 \%$ & USA & 14 \\
\hline & $45-54$ & 12 & $17.39 \%$ & MA over & 20 & $28.99 \%$ & FR & 7 \\
\hline & $55-64$ & 15 & $21.74 \%$ & & & & AUS & 1 \\
\hline & 65 over & 1 & $1.45 \%$ & & & & SP & 0 \\
\hline & & & & & & & MAURITIUS & 0 \\
\hline & & & & & & & GER & 1 \\
\hline & & & & & & & POL & 1 \\
\hline Male Total & & 69 & $100.00 \%$ & & 69 & $100.00 \%$ & & 69 \\
\hline \multicolumn{9}{|l|}{ Female } \\
\hline 64 & $18-24$ & 16 & $25.00 \%$ & Primary & 1 & $1.56 \%$ & IRL & 27 \\
\hline \multirow[t]{8}{*}{$48.12 \%$} & $25-34$ & 18 & $28.13 \%$ & High School & 24 & $37.50 \%$ & UK & 14 \\
\hline & $35-44$ & 5 & $7.81 \%$ & $\mathrm{BA}$ & 22 & $34.38 \%$ & USA & 17 \\
\hline & $45-54$ & 11 & $17.19 \%$ & MA over & 17 & $26.56 \%$ & FR & 2 \\
\hline & $55-64$ & 11 & $17.19 \%$ & & & & AUS & 1 \\
\hline & 65 over & 3 & $4.69 \%$ & & & & SP & 1 \\
\hline & & & & & & & MAURITIUS & 1 \\
\hline & & & & & & & GER & 0 \\
\hline & & & & & & & POL & 1 \\
\hline $\begin{array}{l}\text { Female } \\
\text { Total }\end{array}$ & & 64 & $100.00 \%$ & & 64 & $100.00 \%$ & & 64 \\
\hline
\end{tabular}


